\title{
Public Service Delivery Protests in a Democratic South Africa: A Dilemma for Local Municipalities
}

\author{
Kgalema Mashamaite \\ Department Development Planning and Management, University of Limpopo \\ kgalema.mashamaite@ul.ac.za
}

Doi:10.5901/mjss.2014.v5n25p231

\begin{abstract}
The purpose of this paper is to assess the service delivery challenges facing local municipalities with specific reference to persisting public service delivery protests in South Africa. The advent of a democratic state provided the poor with hope for better life previously denied by the apartheid government for more than four centuries. Their expectations for the new dispensation was the improved socio-economic conditions at local level such as the elimination of poverty, provision of housing, job creation, better health services, better education and general improvement in the quality of their lives. Whilst the efforts by local municipalities to address the concerns of communities in the country, poor socio-economic conditions at local level remains palpable. Two decades after the collapse of apartheid governance system and the advent of a new democratic dispensation, South Africa has observed unprecedented service delivery protests and demonstrations in most local municipalities around the country. The public service delivery in the democratic South Africa particularly at local government level has since been characterised by these costly mass demonstrations and confrontations from poor local communities who express their dissatisfaction and frustrations with the lack of the provision of basic services such as adequate water, proper housing, electricity, education, sanitation, health and employment by their municipality. However, local communities seems not only express their frustrations and dissatisfaction about the provision of services, but also about the failure of local municipalities to engage and integrate communities in the governance and affairs of the municipality. Against this background, the paper argues that the majority of poor people remain sceptical about the capacity of local municipalities to deliver services therefore resorting to mass protests and demonstrations. Thus, this has since put the local municipalities in the country under immense pressure to deliver services in response to the concerns of poor communities.
\end{abstract}

Keywords: public service delivery, public service, service delivery protests, basic services

\section{Introduction}

The widespread service delivery protests within municipalities in South Africa have reached unprecedented levels two decades into democracy. The dawn of a democratic South Africa was met with great enthusiasm and expectation by the majority of the people. The new dispensation to the majority of the people in the country meant the alleviation of poverty, provision of better housing, better health and education facilities, access to adequate water, affordable and reliable electricity and proper sanitation and the overall improvement of life of the majority of the people. The excitement that accompanied the new dispensation was short-lived and later replaced by growing signs of despair with government's inability to render the basic services promised to all citizens, particularly those who were previously disadvantaged by the apartheid regime. As such, majority of people display their frustrations and impatience over slow, poor or lack thereof of service delivery in the form of protests, demonstrations, boycotts, petitions and strikes which are characterized by violence, looting, vandalism, bloodshed and casualties (Zubana, 2011; Clark, 2011). In the past few years, public service delivery protests have been rife in municipalities across South Africa, particularly in the former homelands, with militant communities taking to the streets in remonstration over lack services and poor performance of these municipalities. The provision of basic services in most municipalities has been very slow and failed to meet the expectations of the majority of people (Clark, 2011).

Some municipalities around the country have been put under provincial administration with some officials been investigated of fraud and corruption. This has left the government, in particular most local municipalities around the country, under immense pressure and struggling to deliver basic services to their communities. In an attempt to address concerns and the needs of poor communities, pro-poor approaches such as the integrated development planning, local economic development among others was ensued. However, poor or lack of services and poor socio-economic conditions at local level remains palpable. These conditions have left the majority of poor people sceptical about the 
capacity of local municipalities to deliver services thereby resorting to mass protests, petitions, strikes and demonstrations over the lack or poor service delivery. The subject of service delivery around the country has since become a cliché and a daunting issue for policy makers and municipalities responsible for the provision of basic services (Nleya, 2011). Therefore, it is within this background that this paper aims to evaluate and understand the service delivery challenges in relation to persisting mass protests and poor service delivery facing local municipalities in South Africa.

\section{Public Service Delivery Context}

Public service is defined as "an administrative vehicle by means of which governments deliver all kinds of services to their citizens" (Nengwakhulu, 2009:344). The public service is a government administration system which includes public institutions functioning under the auspices of the South African Public Service Administration mandated by the constitution. According to Nengwakhulu (2009), the public service can be defined as an administrative vehicle by means of which government deliver services in order to meet the needs and expectations of their citizens. The basic services that government is expected to deliver to the public include tangible services such as water, sanitation, housing, electricity, employment, education, health care and infrastructural amenities as well as intangible services such as social aspects like restoring human dignity and respect in delivering such services, building and sustaining quality of life.. Kanyane (2010) argues that human beings would cease to exist without these basic services at their disposal. Public service delivery is therefore the provision of services by the government to all its citizens as their expectations and mandate from the Constitution. The failure to provide these amenities would be in violation of their democratic right to have access to basic services and live a better life.

The dawn of democratic government in South Africa meant new political, social and economic order which created unparalleled expectations and greater hopes for most people, particularly the black majority (Nengwakhulu, 2009). The primary task for the new government was to transform the public service in order to align it to the vision of the new government. However, twenty years into democracy, the widespread service delivery protests around the country proves contrary to these beliefs. The need for a public service that will meet the demands of the new government and the expectation of the public was evident. The new government, therefore, had a new and different mandate, a new set of belief and practices and different expectations from the public. However, the new government inherited a public service of the apartheid regime that was structured and organised only to provide services to the minority rather than provide services to all people. As such, transformation of the public service in South Africa meant going beyond just reform in order to curb the imprints of the apartheid. This situation warranted that the government reshape the existing public service for its appointed role in the new dispensation. Despite the new dispensation and new regulatory frameworks as well as successes achieved, transformation of the public service remains a daunting challenge for the new government.

The Public Service Act (103 of 1994) provide for one single public service in South Africa. This Act ended apartheid administration in that it reintegrated public servants of the nominally independent homelands (bantustans) and self-governing territories into a single government system which comprises of the central (national) government and nine newly created provinces. Section 8 of the Public Service Act (103 of 1994) states that the South African public service constitutes all persons holding fixed positions or permanent additional appointments in the service, and the state educational institutions excluding members of the National Defence Force, the South African Security Agency and the South African Police Intelligence. The powers and duties of government are enshrined in the constitution which provides for the public service consisting of administration in the national and provincial spheres and administration in the local government sphere (Department of Public Service and Administration, 2007). Therefore, the public service in South Africa is guided by the norms and principles outlined in the constitution. The South African public service operates from an environment different from that of the private organizations.

\section{Prescripts for Service Delivery Planning in South Africa}

The transformation of the public service into an efficient and effective instrument to deliver equitable and quality basic services to all citizens and to drive the country's economic and social development has been one of the primary tasks for democratic government since 1994. However, the ability and efforts of the new government to transform the public service which lacked legitimacy and credibility in the eyes of the majority of South Africans has been severely limited by the legacies of the apartheid. Since then, various legislations and policies, all aimed at improving the lives of the people and rendering quality services, have been developed as key to the transformation process of the public service. The transformation of the public service has been undertaken within the new legislative framework by the new government with specific reference to the Constitution or the Republic of South Africa (Act 108 of 1996), Public Service Act (Act 103 of 
1994), White Paper on the Transformation of the Public Service of 1995 and the White Paper on Transforming Public Service Delivery of 1997, Public Service Commission Act (Act 46 of 1997), Public Finance Management Act (Act no. 1 of 1999), Public Service Regulations of 2001 and the Service Delivery Charter among others.

The Public Service Act (Act 103 of 1994) is the principal piece of legislation governing the public service in the country as stipulated in the Constitution of the Republic. The Act seeks to provide for the organisation and administration of the public service of the Republic of South Africa. The Act also regulates and sets out some of the important employment conditions of the public service in the country specifically with regard to terms of office, disciplinary procedures, retirement and dismissal of public service members. The White Paper on Transformation of the Public Service of 1995 and the White Paper on Transforming Public Service Delivery of 1997, popularly known as the Batho Pele White Paper, provide a framework through which the public services are to be delivered in the country. The White Paper sets out the eight transformation priorities which serve as key directives to the public service towards being efficient, effective and responsive to the developmental needs of all citizens in the country (Wilson, 2012). The notion is that the public service in the country would be measured based on its effectiveness in delivery quality services which meet the basic needs of all citizens (Crous, 2004). Thus, access to decent public services should no longer be a privilege to be enjoyed by the minority but now it is the rightful expectation of all citizens specifically those previously disadvantaged by apartheid system in the country.

The Sections 195 and 196 of the Constitution give effect to the Public Service Commission Act (Act 46 of 1997) and outline its mandate. According to the Constitution, the commission must investigate, monitor and evaluate the organisation and administration of the public service through the evaluation of achievements, or lack thereof, of government programmes. The commission is further obligated to promote measures that will ensure effective and efficient performance within the public service and to promote values and principles for public administration as enshrined in Chapter 10 of the Constitution. Thus, the Public Service Commission of South Africa has constitutional obligation to ensure that the public service is administered and managed in an effective and efficient manner.

The Public Finance Management Act (PFMA) (Act no. 1 of 1999) is one of the most important pieces of legislation enacted by the first democratic government in South Africa. The Act promotes the objective of good financial management in the public service in order to maximise service delivery through the effective and efficient use of the limited government resources. The Act gives effect to sections 213 and 215 of the Constitution of the Republic of South Africa (Act no. 108 of 1996) for both the national and provincial spheres of government. According to these sections the national legislature must establish a national treasury, introduce uniform treasury norms and standards, prescribe measures to ensure transparency and expenditure control in all spheres of government, and set the operational procedures for borrowing, guarantees, procurement and oversight over the various national and provincial revenue funds. The PFMA adopts an approach to financial management which focuses on outputs and responsibilities rather than the rule driven approach of the previous Exchequer Acts. The PFMA is part of the broader strategy on improving financial management in the public service. According to the National Treasury, PFMA supersede other various national and provincial Exchequer Acts and the Reporting of Public Entities Acts currently in place.

Part Three: $\mathrm{C}$ of the Public Service Regulations (PSR) advances the implementation of Batho Pele by making provision for the development of Service Delivery Improvement Programmes (SDIPS) by all departments within the public service (Wilson, 2012:27). According to PSR, each department including municipalities must establish and sustain SDIP, publish annual statement of public service commitment which sets out service standards that all citizens should expect from each department and assists in explaining how such service standard will be achieved. Thus, each department is expected to provide quality services to all citizenry with greatest value for money and setting measurable objectives through clearly defined service standards and optimal use of available resources (Wilson, 2012). The aim of SDIPs is to provide mechanism for sustainable, constant, effective, credible and incremental improvement in service delivery. The SDIPs provide basis for publishing information which sets out the service delivery standards and a Service Delivery Charter. The Service Delivery Charter sets out service delivery standards that all citizens should anticipate from all government departments. The objective of Service Delivery Charter include among others, maintaining set service delivery standards and accelerating transformation of the public service from rules-bound bureaucracy to a more resultsdriven (Wilson, 2012). In this regard, service delivery standards help to measure the extent to which set objectives are met and whether the needs of all citizens are addressed effectively and efficiently.

\section{Factors Undermining Local Municipalities' Service Delivery Commitment}

Local municipalities are constitutionally mandated to provide basic services and promote social and economic development of their local communities. Not only should municipalities provide services to the communities but also 
ensure that those services are sufficient and sustainable (Madzivhandila \& Asha, 2012). Despite their efforts and relative successes in promoting socio-economic development, municipalities around South Africa are still facing serious and persisting challenges of underdevelopment, poverty, inequality and unemployment. These are some of the catalysts culminating in the majority of poor people taking to the streets to raise their dissatisfaction and frustrations over lack of or poor service delivery (Managa, 2012). Managa (2012) identifies the problems of institutional capacity, mismanagement of funds, high levels of corruption and lack of public participation as key challenges hampering the performance of local municipalities to deliver services. This has left authors and ordinary people to conclude that the current local government is failing to provide services to communities. However, this does not suggest that local municipalities are dysfunctional and ineffective in addressing the basic needs of communities (Madzivhandila \& Asha, 2012), but rather failing to cope with the amount of backlogs and challenges relating to governance and mismanagement of resources. The critiques of local municipalities' inabilities to provide basic services does not, however, take into consideration of the triumphs achieved, especially considering that the new local government system is still young.

There is evidence that most local municipalities have lack of expertise in the fields such as project management, financial management and engineering which left these municipalities inadequately staffed ultimately leading to huge service delivery backlogs around the country (Managa, 2012). This has undermined the capabilities of municipalities to provide basic services and complete development projects leaving poor communities across the country without the opportunity to adequately access basic services they have been constitutionally promised to meet their needs. The failure to delivery services is closely associated with maladministration of resources and lack of capacity to complete development projects. There is a growing concern about the ability of most municipalities around the country to manage their finances. The 2010/11 financial report by the Auditor-General indicated that only seven municipalities audited around the country received clean audit during that financial year, painting a bleak picture of financial mismanagement. The financial mismanagement in almost all municipalities is associated with understaffing, poor planning, poor management, lack of financial and managerial skills which exacerbated underspending and overspending as well as unauthorised, irregular and wasteful expenditure leading to suspicions of corruption and fraud (Managa, 2012; Nengwekhulu, 2009). This led to some municipalities being placed under provincial administration in order to address these problems.

Madzivhandila \& Asha (2012) mention the widespread corruption across all levels of government in South Africa as one of the fundamental challenges that undermine both the credibility and ability of municipalities to provide basic services to communities. Clearly, high levels of corruption violate the human rights of ordinary citizens and undermine the values enshrined in the Constitution. Additionally, the persisting corruption further cripples the local government system and blurs the line of accountability thereby undermining the democratic values. Lack of participation by communities in the municipal affairs also exacerbated the persisting service delivery backlogs leaving communities frustrated and dissatisfied. The exclusion of communities in the decision making processes by municipalities blurs the lines of accountability, transparency, ownership and responsiveness leaving communities with no choice but to resort to mass protests. The Municipal Systems Act (Act 32 of 2000) provides the provision for communities to participate in the integrated development planning and implementation processes of their municipalities in collaboration with other stakeholders. Despite this, municipalities are unable to allow communities to meaningfully participate and influence in the decision making. In spite of strives made to provide public services, almost all municipalities are still faced with these challenges and continuing to struggle to provide services to all South Africans. This background clearly indicates that challenges facing remain complex and diverse for municipalities across the country to cope with the demands of ordinary citizens.

\section{Public Service Delivery Protests in a Democratic South Africa}

Two decades into democracy, South Africa observed a wave of protests associated with poor or lack of service delivery around the country. According to Managa (2012), poor service delivery elicited protests across the country which brought local municipalities under the spotlight. Since then, local municipalities has been a subject of criticisms for failing to implement their developmental mandate. Alexander (2010) argues that the service delivery protests across the country became rife in 2004 which varied from protest to protest and from community to community. In 2004, only 10 widely publicised protest incidents were reported across the country and this number rose to 35 in 2005 which marked the beginning of social unrests characterised by violent acts from dissatisfied and angry communities. However, during 2006, a year of local government elections, the country observed the least number of protests but shoot up again in 2007 (see Figure 1 below) (Alexander, 2010). This could be as a result of promises made by political parties during their campaigns for these particular elections which raised the hopes and expectations of communities that after elections their socio- 
economic problems would be addressed. However, no linkage has been documented between elections and these particular protests.

A period between 2009 and 2010, staggering 105 and 111 numbers of protests were recorded respectively in all provinces with the exception of Limpopo while in 2011 there were fewer protests around the country (Managa, 2012). According to the Municipal IQ, an independent monitor of service-delivery protests and trends, there were staggering 584 protests between 2009 and August 2013 with 2012 recording the highest number of protests since the first recorded protests in 2004 and accounted for 173 service-delivery protests. One of the reasons for the escalation of these protests could be the fact that the previous government administration failed to implement the promises made in the manifesto of the ruling party for better life for all. The election manifestos from different political parties have also created disquiet, as parties make promises most likely to satisfy voters during each new election campaign thereby raising the public's expectations, creating false perceptions that, following the election, communities will receive the services promised (Managa, 2012). The ruling party, in line with their slogan 'Better life for all' and the government' commitment to the Millennium Development Goals, promised citizens to improve their living conditions by halving poverty, creating employment and constant economic growth thereby raising their expectations for better life. Thus, once these bags of promises are not fully met, communities then resort to protests against poor services. Another reason associated with growing signs of despair and high levels of protests is that of the political factions within the ruling party both at national and local level particularly after the Polokwane conference. Often service delivery protests have been associated with political factions as a mechanism to subvert the government. However, there is no clear evidence suggesting that political factions fuelled these particular protests. These figures indicate that the number of service delivery protests across the country has been increasing annually since 2004 to date.

Figure 1: Number of service delivery protests between 2004 and 2011

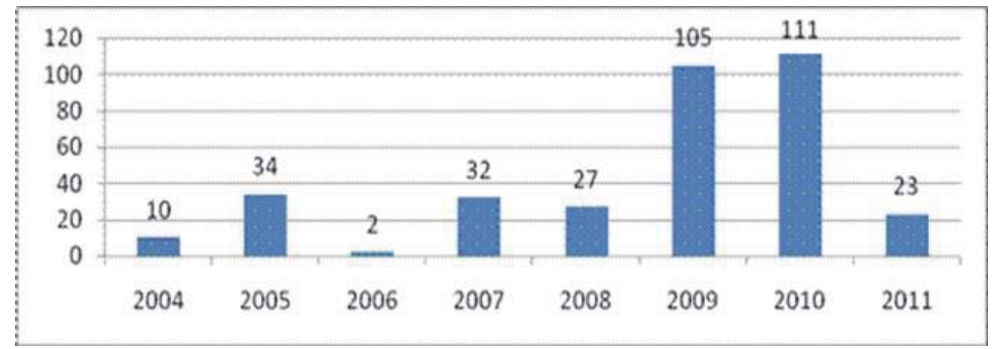

Source: Municipal IQ: Municipal Hotspots Monitor

These protests were accompanied by violent incidents which in most instances resulted in loss of life, destruction of property, looting, burning of tyres and blockage of access roads as communities display their dissatisfaction, frustrations and anger with lack of basic services such as water, employment, electricity, housing, education, health care, sanitation and etc. in their communities. The attacks on foreign nationals in acts of xenophobia, in the misguided belief that foreigners were reducing job opportunities for South Africans, and the callous response from the police service have resulted in the deaths of many (Managa, 2012). A total of 43 protesters were reportedly killed in confrontations with police forces between 2004 and 2014 excluding the 37 miners killed during the strike at Marikana in 2012 with over 80\% of these protests turning violent especially between 2007 and 2013 (Grant, 2014). Communities such Tlokwe and Marikana in the North West, Bekkersdal and Khutsong in the West Johannesburg, Diepsloot in the North Johannesburg, Zamdela in Sasolburg, Khayelisha in Western Cape, Malamulele in Limpopo and Ficksburg in Free State have since been labelled hotspots for violent protests. Some of these protests in these communities have been labelled as a conspiracy by some political factions to destabilise the government, especially in the run-up to elections. However, there is no clear correlation between elections and protests but most of the protests ensued after the 2009 general elections as a result of the inability of the poor to access basic services. 
Figure 2: Protesters in the North West

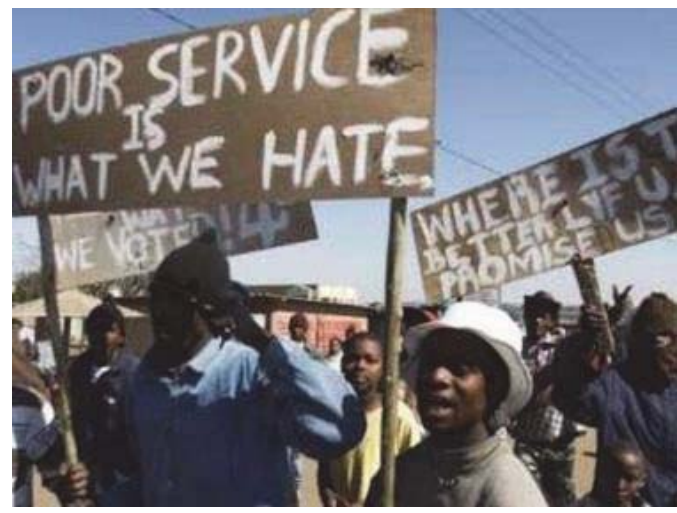

Source: DefenceWeb, 2011
Figure 3: Armed protesters in action

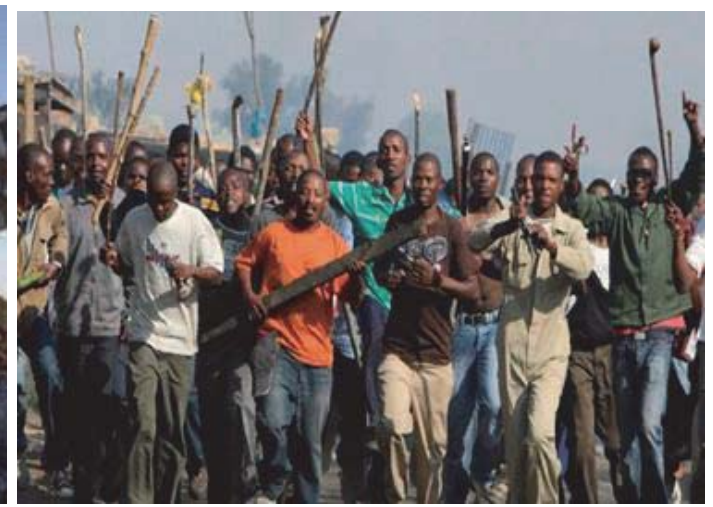

Source: Reuters, 2014

Generally, the protests are closely associated with and as a result of the following interrelated aspects; a) ineffectiveness and the lack of responsiveness to the needs of citizens seem jointly to comprise the main reason for these protests; b) the organisational culture of municipalities does not lend itself to effective service delivery; $c$ ) the intergovernmental system does not favour local municipalities; d) most municipalities are forced to carry the burden of failed policies; e) the reaction of the role-players to the protests has been mixed, ranging from an acceptance of responsibility, to a total disregard for the relevance of the demands made by protesters (Marais, Matebesi, Mthombeni, Botes and van Rooyen, 2008; Atkinson; 2007).

Most protesters have indicated that their actions are as a result of lack of services and their exclusion in the decision making processes in their municipalities. Interestingly, most communities accuse local municipalities of being unresponsive to their demands, corruption, unfulfilled promises, nepotism and exclusion as well as failing to address inequalities and unemployment (Nleya, 2012; Sebugwawo, 2012; Hough, 2008). Pity is that some of these municipalities around the country have not shown interest in responding to the grievances put forward by their communities. The rising levels of protests should be a warning to municipalities that the problems faced by poor people need to be addressed urgently and given greater attention. The persisting service delivery has left most commentators to conclude that our municipalities are in crisis and that there is a ticking time bomb in South Africa.

\section{Conclusion}

Very few local municipalities in South Africa have significantly contributed to the achievement of social and economic development improvements of communities since the new democratic municipal dispensation in the late 2000 (Cooperative Governance and Traditional Affairs, 2009). Municipalities around the country have improved the living conditions in some communities thereby increasing accessibility of some basic services and increased economic opportunities. Despite the achievements advanced since the new dispensation, most communities still find themselves living in harsh conditions which perpetuate the prevalence of mass protests, demonstrations and petitions over lack of service delivery. Since then, local municipalities have shown signs of distress and struggling to meet the needs of their communities. Protests over poor service delivery have since become an endemic feature of South Africa's socio-political landscape, particularly at local level leaving the service delivery at a precarious state. These protests remain a consistent and worrying factor in most communities and for municipalities across the country. Thus, painting bleak picture about local municipalities and its inability to provide basic services to communities. These conditions have currently left most municipalities in a dire state of crisis.

Some municipalities have been placed under administration due to maladministration and financial mismanagement with some officials under investigation of corruption and fraud undermining efforts to provide services. Thus, communities have lost hope and confidence on the municipalities' lack of responsiveness, accountability, transparency, efficiency and effectiveness. Municipalities' efforts to address inequalities, unemployment and poverty as well as lagging service delivery remain crucial as the ultimate solution to the prevailing social phenomena. Clearly, local municipalities in the country still have long way to go and as long as there is poor service delivery in most communities, more protests will persist, causing serious instability. Therefore, urgent interventions at municipal level are required to 
address deteriorating socio-economic conditions of most communities around the country by strengthening human resource capacity, dealing with corruption decisively and objectively, build financial capacity of employees, strengthen performance management system and ensure accountability, transparency and participation in the municipalities. This would avoid the possibilities of ensuing a social revolution and instability around South Africa.

\section{References}

Alexander, P. (2010). Rebellion of the poor: South Africa's service delivery protests- A preliminary analysis. Review of African Political Economy, 37(123), 25-40.

Atkinson, D. (2007). Taking to the streets: has developmental local government failed in South Africa? In S. Buhlungu, J. Daniel, R. Southall \& J. Lutchman (Eds), State of the nation: South Africa 2007. Pretoria: Human Sciences Research Council (HSRC).

Clark, A. (2011). The impact of service delivery on South Africa's local government elections. Article published in the Think Africa Press website on the $08^{\text {th }}$ April 2011. Accessed: 05-06-2014.

Cooperative Governance and Traditional Affairs. (2009). State of local government in South Africa. Overview Report: National State of Local Government Assessments. Working Documents. Pretoria: COGTA.

Crous, M. (2004). Service delivery in the South African public service: Implementation of the Batho Pele Principles by Statistics South Africa. Journal of Public Administration, 39(4.1), 574-589.

Department of Public Service and Administration. (2007). Lessons of the transformation process. Pretoria: DPSA.

Grant, L. (2014). Research shows sharp increase in service delivery protests. Article published in the Mail and Guardian website on the 12th February 2014. Accessed: 09-06-2014.

Hough, M. (2008). Violent protest at local government level in South Africa: Revolutionary potential? South African Journal of Military Studies, 36(1), 1-13.

Kanyane, M.H. (2010). Public service delivery issues in question. In K. Kondlo \& M.H. Maserumule (Eds). The Zuma administration: critical challenges (pp. 77-94). Cape Town: HSRC Press.

Nleya, N. (2011). Linking service Delivery and protest in South Africa: An exploration of evidence from Khayelitsha. Africanus, 50(1), 313.

Madzivhandila, T.S. \& Asha, A.A. (2012). Integrated development process and service delivery challenges for South Africa's local municipalities. Journal of Public Administration, 47(1.1), 369-378.

Managa, A. (2012). Unfulfilled promises and their consequences: A Reflection on Local Government Performance and the Critical issue of Poor Service Delivery in South Africa. Africa Institute of South Africa: Policy Brief No.76. Pretoria: AISA.

Nengwakhulu, R.H. 2009. Public service delivery challenges facing the South African public service. Journal of Public Administration, 44(2), 341-363.

Republic of South Africa (1996). Constitution of the Republic of South Africa. 1996. Pretoria: Government Printer.

Republic of South Africa (2000). Municipal Systems Act, 2000 (Act 32 of 2000). Pretoria: Government Printer.

Republic of South Africa (1999). Public Finance Management Act, 1999 (Act no. 1 of 1999). Pretoria: Government Printer.

Republic of South Africa (1994). Public Service Act, 1994 (103 of 1994). Pretoria: Government Printer.

Republic of South Africa (1997). Public Service Commission Act, 1997 (Act 46 of 1997). Pretoria: Government Printer.

Republic of South Africa (2001). Public Service Regulations. 2001. Pretoria: Government Printer.

Republic of South Africa (1995). White Paper on the Transformation of the Public Service. 1995. Pretoria: Government Printer.

Republic of South Africa (1997). White Paper on Transforming Public Service Delivery. 1997. Pretoria: Government Printer.

Sebugwawo, M. 2012. Service delivery protests in South Africa: Lessons for municipalities. Service Delivery Review, 9(2), 7-8.

Wilson, M. 2012. A new integrated and holistic approach to service delivery planning. Service Delivery Review, 9(2), 26-29.

Zubana, P. 2011. Alternative service delivery models for the South African public service for the year 2020. Master's Research Report. University of Stellenbosch.

Marais, L., Matebesi, Z., Mthombeni, M., Botes, L. and van Rooyen, D. 2008. Municipal unrest in the Free State (South Africa): a new form of social movement? Politeia, 27(2), 51-69. 